\title{
PENGARUH HARGA, KUALITAS PRODUK DAN PROMOSI TERHADAP KEPUTUSAN PEMBELIAN 13 PRODUK PATTAYA CORNER KOTA SALATIGA
}

\author{
Murtadho Kesuma'; Dessy Fitria²; Ahmad Ulil Albab Al Umar3 \\ Fakultas Ekonomi dan Bisnis Islam IAIN Salatiga ${ }^{1,2,3}$
}

$\underline{\text { murtadhokesuma.psfebi@gmail.com }}^{1}$; $\underline{\text { dessy.psfebi@gmail.com }}^{2}$; $\underline{\text { ahmadulil.asfebi@gmail.com³ }}^{3}$

\begin{abstract}
ABSTRAK
Penelitian ini bertujuan untuk mengetahui alasan dibalik fluktuatifnya jumlah penjualan dari produk Pattaya Corner dengan menggunakan variabel harga, kualitas produk, dan promosi terhadap keputusan pembelian produk Pattaya Corner. Data primer digunakan dalam penelitian ini dan disebarkan melalui kuesioner. Populasi dalam penelitian ini adalah masyarakat yang bertempat tinggal di kota Salatiga, sedangkan untuk sampel sendiri yaitu konsumen dari Pattaya Corner kota Salatiga sebanyak 106 sampel. Pengambilan sampel ini dilakukan dengan Random Sampling. Pendekatan Kuantitatif digunakan dalam penelitian ini dengan uji validitas, uji reliabilitas, uji t dan uji F. Hasil penelitian menggunakan SPSS versi 23 menunjukkan bahwa variabel harga, kualitas produk, dan promosi sama-sama berpengaruh positif dan signifikan terhadap keputusan pembelian. Variabel harga berpengaruh sebesar $52 \%$, untuk variabel kualitas produk berpengaruh sebesar $46 \%$, dan variabel promosi berpengaruh sebesar $54 \%$ dan yang paling dominan dalam pengambilan keputusan pembelian.
\end{abstract}

Kata kunci: Harga, Kualitas, Promosi, Keputusan, Salatiga

\section{Abstract}

This study aims to see the reasons based on the fluctuation of the sales volume of Pattaya Corner products using price, product quality, and promotion variables for the decision to purchase Pattaya Corner products. Primary data used in this study and distributed through a questionnaire. The population in this study are people who live in the city of Salatiga, while for the sample itself, namely consumers from Pattaya Corner, Salatiga city as many as 106 samples. This sample was taken by random sampling. The quantitative approach used in this study was the validity test, reliability test, $t$ test and $F$ test. The results of the study using SPSS version 23 showed that price, product quality, and promotion variables both had a positive and significant effect on purchasing decisions. The price variable has an effect of $52 \%$, for the product quality variable has an effect of $46 \%$, and the promotion variable has an effect of $54 \%$ and is the most dominant in making purchasing decisions.

Keywords: Price, Product, Promotion, Decision, Salatiga

Diterima: 30 Maret 2021; Direvisi: 6 April 2021; Diterbitkan: 20 April 2021

\section{PENDAHULUAN}

Berkembangnya dunia wirausaha yang semakin pesat menyebabkan para produsen menghadapi persaingan yang ketat. Faktanya, sekarang ini semakin maraknya usaha yang menawarkan produk yang sama. Oleh karena itu, inovasi dari suatu produk harus dilakukan oleh produsen agar usaha yang dijalankannya selalu survive dan dapat menarik minat konsumen. Minat konsumen sendiri menjadi salah satu hal yang harus dipertimbangkan oleh produsen karena terkait dengan pembelian yang akan dilakukan oleh 
konsumennya. Dari minat konsumen untuk membeli suatu produk didapatlah keputusan pembelian akan suatu produk.

Keputusan pembelian adalah keputusan atas kepemilikan suatu barang karena telah melakukan serangkaian proses transaksi. Dalam membeli suatu produk, konsumen tidak langsung memilih produk tersebut secara langsung, namun beberapa hal harus diperhatikan. Pada saat inilah produsen harus benarbenar bisa membaca apa yang diinginkan konsumen. Inovasi dari produk yang ditawarkan sangatlah penting untuk diperhatikan produsen, karena hal tersebut akan menjadi ciri khas dari produk dan akan menambah minat konsumen untuk mengambil keputusan pembelian akan produk tersebut.

Pattaya Corner merupakan bisnis yang bergerak di bidang penjualan minuman yang sudah eksis di kota Salatiga yang memang bisa membaca peluang yang diinginkan konsumennya, hal ini terbukti dengan penjualannya yang tinggi disetiap bulannya. Ciri khas yang dimiliki benar-benar dapat memikat konsumennya ditambah sudah memiliki market share yang cukup luas dengan bukti memiliki beberapa cabang di kota Salatiga. Hal ini terbukti dengan jumlah penjualannya tiap minggu pada bulan November 2020 yang tinggi.

\begin{tabular}{cc}
$\begin{array}{c}\text { Tabel 1. Penjualan Pattaya Corner November 2020 Cabang } \\
\text { Selasar }\end{array}$ \\
\hline Minggu & Penjualan \\
\hline 1 & 520 \\
2 & 485 \\
3 & 508 \\
4 & 538
\end{tabular}

Sumber: wawancara, 2020

Penjualan yang fluktuatif ini merupakan topik yang menarik untuk diteliti karena terkait dengan produk yang sudah eksis dikalangan masyarakat kota Salatiga yang mempengaruhi dalam pengambilan keputusan pembelian. Faktor-faktor yang mempengaruhi keputusan pembelian sendiri diantaranya yaitu harga, kualitas produk, dan promosi. Oleh karena itu variabel harga, kualitas produk, dan promosi diambil untuk menguji pengambilan keputusan pembelian produk Pattaya Corner. Perilaku konsumen menjadi hal yang sangat mendasar pada konsumen dalam menentukan keputusan pembelian (Albab Al Umar, A., Mustofa, M., Fitria, D., Jannah, A., \& Arinta, Y, 2021).

\section{LANDASAN TEORI}

\section{Harga}

Pengertian harga menurut Indriyo dalam Danang (2015 : 131) merupakan nilai yang dinyatakan dalam satu mata uang atau alat tukar terhadap suatu produk tertentu. Besar kecilnya nilai atau harga tidak hanya dipengaruhi oleh faktor fisik saja, namun juga faktor lain seperti psikologis yang juga mempengaruhi harga. Besar kecilnya harga suatu produk tergantung dari penetapan harga dari produsen, semakin tinggi manfaat yang dapat dirasakan konsumen dari mengkonsumsi suatu produk maka semakin tinggi pula harga yang akan dikeluarkan. Menurut Swastha dalam Christy dkk (2017 : 2223) tujuan dari penetapan harga untuk meliputi kelangsungan hidup, memaksimalkan keuntungan, maksimalisasi penjualan, dan prestise atau gengsi.

\section{Kualitas Produk}

Produk menurut Harman (2017 :31) adalah suatu barang nyata yang dapat terlihat atau berwujud dan bahkan dapat 
dipegang yang dirancang untuk memuaskan keinginan atau kebutuhan seperti komputer, mobil, gosok gigi, dan lain-lain. Sedangkan kualitas produk menurut Kotler dan Amstrong dalam Rhendria (2010 : 339) adalah kemampuan produk untuk menunjukkan berbagai fungsi termasuk didalamnya ketahanan, kehandalan, ketepatan, dan kemudahan dalam penggunaan. Kualitas produk yang baik tentu saja akan menambah minat konsumen untuk membeli produk tersebut, oleh karena itu produsen harus benar-benar memperhatikan bagaimana produknya diolah agar kepercayaan dari konsumen tetap terjaga.

\section{Promosi}

Promosi menurut Indriyo dalam Danang (2015 : 158) yaitu kegiatan yang ditujukan untuk mempengaruhi konsumen agar mereka dapat menjadi kenal akan produk yang ditawarkan oleh perusahaan kepada mereka dan kemudian mereka menjadi senang lalu membeli produk tersebut. Promosi yang dilakukan oleh produsen atau wirausaha dapat dilakukan dengan menggunakan beberapa cara, yaitu periklanan, promosi penjualan, publisitas, dan personal selling yang biasa disebut dengan bauran promosi. (Soehardi et al., 2020).

\section{Keputusan Pembelian.}

Menurut Kotler dan Amstrong dalam dalam Deni dan Rita (2016 : 47) keputusan pembelian adalah keputusan pembeli tentang merek mana yang yang dibeli. Dua faktor yang dapat muncul dalam keputusan pembelian yaitu niat untuk membeli dan keputusan pembelian itu sendiri. Menurut Kotler (2002 : 204) mengemukakan bahwa proses pengambilan keputusan pembelian ada lima tahap yaitu :

a. Tahap pengenalan kebutuhan, yaitu tahap dimana konsumen menyadari masalah atau kebutuhan.

b. Tahap pencarian informasi, yaitu tahap dimana konsumen mencari informasi lebih tentang apa yang ingin didapatkannya.

c. Tahap evaluasi alternatif, yaitu tahap dimana konsumen menggunakan informasi untuk mengevaluasi beberapa produk yang sudah didapatkan.

d. Tahap keputusan pembelian, tahap dimana konsumen membeli produk yang sudah dipilih.

e. Tahap perilaku pasca pembelian, tahap dimana konsumen merasa puas atau tidak mengenai produk yang sudah dibeli.

\section{Hubungan Harga, Kualitas Produk, dan Promosi Terhadap terhadap Keputusan Pembelian}

Faktanya, harga merupakan komponen yang penting dalam memutuskan untuk membeli suatu produk. Harga yang bervariasi seperti tersedianya harga dari yang termurah sampai harga termahal juga dapat menambah pengambilan keputusan pembelian konsumen karena minat konsumen akan suatu produk tidak hanya tertuju pada satu produk. Produk yang memiliki harga yang lebih rendah dari harga produk lain tetapi masih memperhatikan kualitas juga dapat menarik minat konsumen untuk membeli produk tersebut. Seperti hal nya pada produk pattaya corner yang memiliki harga terjangkau namun tetap memperhatikan kualaitasnya sangat berpengaruh terhadap hasil penjualannya. Oleh karena itu, harga menjadi salah satu 
faktor penting dalam pengambilan keputusan pembelian.

Baik buruknya kualitas suatu produk akan mempengaruhi konsumen dalam mengambil keputusan pembelian akan suatu produk. Seperti halnya dalam mengolah produk akan berpengaruh terhadap rasa. Produk yang memiliki ciri khas atau brand akan menambah minat konsumen untuk membeli produk tersebut, karena konsumen merasa puas setelah mengkonsumsi produk yang memiliki ciri khas tersendiri. Oleh karena itu, kualitas produk juga menjadi faktor yang mempengaruhi pengambilan keputusan pembelian.

Promosi merupakan salah satu cara perusahaan untuk menarik minat konsumen untuk mengambil keputusan pembelian akan produknya. Dengan adanya promosi, konsumen akan lebih tertarik untuk membeli produk tersebut karena akan lebih menguntungkan untuk konsumen itu sendiri. Sehingga promosi juga menjadi salah satu faktor yang mempengaruhi keputusan pembelian .

Penelitian yang dilakukan Santri dan Rusda (2016) menunjukkan bahwa variabel harga berpengaruh positif dan signifikan terhadap keputusan pembelian. Selanjutnya, Penelitian yang dilakukan Melita (2016) menunjukkan bahwa kualitas produk berpnegaruh signifikan terhadap keputusan pembelian. Dan penelitian yang dilakukan oleh Hesti dan Sri (2014) menunjukkan bahwa promosi berpengaruh signifikan terhadap keputusan pembelian.

\section{Kerangka Penelitian}

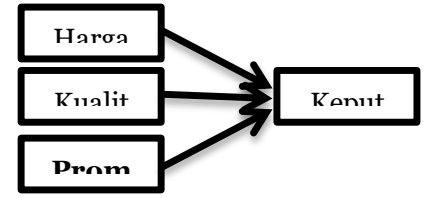

Gambar 1. Kerangka Penelitian

\section{Hipotesis}

H1: Harga berpengaruh positif dan signifikan terhadap keputusan pembelian

H2: Kualitas produk berpengaruh positif dan signifkan terhadap keputusan pembelian

H3: Promosi berpengaruh positif dan signifikan terhadap keputusan pembelian

\section{METODE PENELITIAN}

Jenis penelitian ini menggunakan pendekatan kuantitatif. Populasi dalam penelitian ini adalah masyarakat yang bertempat tinggal di kota Salatiga. Sedangkan sampel dalam penelitian ini diambil menggunakan Random Sampling yang mana sampel penelitian ini adalah konsumen dari Pattaya Corner sebanyak 106 responden. Data yang digunakan merupakan data primer yang didapat dari penyebaran kuesioner selama seminggu dari 18 sampai 25 November 2020.

Dalam penelitian ini dilakukan analisis dalam beberapa tahap. Tahap yang pertama yaitu uji validitas yang mana untuk menguji validitas dari instrumen penelitian yang digunakan dalam pengumpulan data. Tahap yang kedua yaitu uji reliabilitas yang digunakan untuk mengukur tingkat kepercayaan sebuah instrument penelitian. Tahap ketiga dilakukan uji regresi, yang bertujuan untuk mengetahui apakah ada pengaruh variabel independent atau bebas terhadap variabel dependen atau terikat dengan menggunakan uji $\mathrm{F}$ dan uji t.

\section{HASIL PENELITIAN DAN PEMBAHASAN}

\section{Analisis Deskriptif Statistik}


Berdasarkan olah data hasil SPSS didapatkan demografi responden yang tertera pada tabel 2 sebagai berikut :

Tabel 2. Profil Responden

\begin{tabular}{ll}
\hline Demographic & Percentage \\
\hline Gender & \\
Laki-laki & 20.8 \\
Perempuan & 79.2 \\
& \\
Umur & \\
$10-15$ & 3.8 \\
$15-20$ & 68.9 \\
$>20$ & 27.4 \\
& \\
Status & \\
Pelajar & 9.4 \\
Mahasiswa & 84.9 \\
Swasta & 4.7 \\
Lainnya & 0.9
\end{tabular}

Sumber: Data diolah oleh Peneliti 2020

Berdasarkan tabel 2 diatas bahwa jumlah responden adalah 106 responden yang mana 20,8\% berjenis kelamin lakilaki dan 79,2\% berjenis kelamin perempuan. Dan pada bagian status terdapat pelajar sebanyak 9,4\%, mahasiswa sebanyak 84,9\%, swasta sebanyak 4,7\%, dan lainnya sebanyak 0,9\%. Sedangkan informasi umur dari responden yaitu untuk umur 10 sampai 15 tahun sebanyak 3,8\%, untuk umur 16 sampai 20 tahun sebanyak 68,9\%, dan untuk umur lebih dari 20 tahun sebanyak $27,4 \%$.

\section{Uji Validitas dan Reliabilitas}

Tabel 3. The Result of KMO and Bartlett of Sphericity

\begin{tabular}{|c|c|}
\hline Testing & Value \\
\hline Sample Adequacy KMO & 0.888 \\
\hline & 0.000 \\
\hline
\end{tabular}

Dari tabel uji KMO dan Barteltt of sphecirity diatas didapatkan nilai dari KMO yaitu 0,888 yang artinya nilainya lebih baik. Sedangkan untuk nilai Bartlett of Sphecirity yaitu 0,000 yang artinya bahwa hasilnya signifikan. Dari uji validitas maka dapat disimpulkan bahwa penelitian ini valid.

Jenis data yang digunakan dalam penelitian ini adalah data primer yang didapatkan melalui kuesioner dengan pemilihan jawaban yaitu skala linier 5 poin. Penilaian dalam skala yang digunakan yaitu 1 (sangat tidak setuju), 2 (tidak setuju), 3 (netral), 4 (setuju), dan 5 (sangat setuju). Dalam menguji instrumen ini digunakan uji validitas dan reabilitas. Hasil dari uji validitas dan uji reliabilitas dapat dilihat pada tabel 4 dan tabel 5

Tabel 4. Convergent Validity and Reliability Test

\begin{tabular}{|c|c|}
\hline Item & Loading \\
\hline \multicolumn{2}{|l|}{ Kesesuaian Harga $(\mathrm{CR}=0,804)$} \\
\hline $\begin{array}{l}\text { Harga pattaya corner mempengaruhi } \\
\text { saya dalam membeli produk tersebut } \\
\text { Harga yang terjangkau akan menambah }\end{array}$ & 0.811 \\
\hline $\begin{array}{l}\text { keinginan saya untuk membeli pattaya } \\
\text { corner }\end{array}$ & 0.818 \\
\hline $\begin{array}{l}\text { Harga pattaya corner memenuhi } \\
\text { harapan saya }\end{array}$ & 0.790 \\
\hline $\begin{array}{l}\text { Informasi harga dapat dimengerti } \\
\text { dengan jelas }\end{array}$ & 0.790 \\
\hline $\begin{array}{l}\text { Harga pattaya corner sesuai dengan } \\
\text { kualitas produk }\end{array}$ & 0.769 \\
\hline $\begin{array}{l}\text { Harga pattaya corner sesuai dengan } \\
\text { kuantitas produk }\end{array}$ & 0.758 \\
\hline $\begin{array}{l}\text { Harga pattaya corner sesuai dengan } \\
\text { budget konsumen }\end{array}$ & 0.760 \\
\hline $\begin{array}{l}\text { Harga pattaya corner sesuai keinginan } \\
\text { konsumen }\end{array}$ & 0.750 \\
\hline \multicolumn{2}{|l|}{ Bahan Baku $(\mathrm{CR}=0.778)$} \\
\hline $\begin{array}{l}\text { Bahan baku yang digunakan dapat } \\
\text { dimengerti oleh konsumen }\end{array}$ & 0.762 \\
\hline $\begin{array}{l}\text { Bahan baku yang digunakan fresh dan } \\
\text { aman }\end{array}$ & 0.699 \\
\hline $\begin{array}{l}\text { Bahan baku yang digunakan fresh dan } \\
\text { aman }\end{array}$ & 0.729 \\
\hline $\begin{array}{l}\text { Bahan baku yang digunakan baik dan } \\
\text { higienis }\end{array}$ & 0.709 \\
\hline $\begin{array}{l}\text { Kebersihan } \\
(\mathrm{CR}=0.764)\end{array} \quad$ dan $\quad$ Tampilan & \\
\hline $\begin{array}{l}\text { Dalam proses pembuatan dilakukan } \\
\text { dengan bersih dan aman }\end{array}$ & 0.703 \\
\hline $\begin{array}{l}\text { Tempat jualan bersih, nyaman, dan } \\
\text { banyak cabang }\end{array}$ & 0.716 \\
\hline $\begin{array}{l}\text { Tampilan pattaya corner memiliki ciri } \\
\text { khas tersendiri }\end{array}$ & 0.732 \\
\hline $\begin{array}{l}\text { Tampilan pattaya corner dapat diingat } \\
\text { dengan mudah oleh konsumen }\end{array}$ & 0.683 \\
\hline
\end{tabular}




\section{Promosi $(\mathrm{CR}=0.864)$}

Pattaya corner sering mengiklankan produknya Pattaya corner memiliki akun di media $\begin{array}{lll}\text { sosial dan aktif } & & \\ \text { Promosi sering diberikan dalam }\end{array}$ pembelian online diberikan dalam Promo harga dapat didapatkan siapapun

0.845

0.833

0.802

0.826

Keputusan Pembelian $(\mathrm{CR}=0,749)$

Saya membeli pattaya corner karena adanya kebutuhan

Saya tertarik membeli pattaya corner karena produknya enak dan harga terjangkau

Saya membeli pattaya corner karena produknya sudah terkenal dan memiliki ciri khas tersendiri di kota Salatiga

Saya membeli pattaya corner karena

kemudahan akses pembelian baik itu

ditempat langsung maupun pembelian online

Sumber: Data diolah oleh Peneliti 2020

Tabel 4 menunjukkan hasil dari uji reliabilitas dan nilai cronbach alpha. Dari tabel uji validitas dan reliabilitas dapat diketahui bahwa nilai dari variabel harga yang tercermin dari indikator kesesuaian harga adalah 0,804 . Sedangkan nilai dari variabel kualitas produk yang tercermin dari dua indikator, indikator yang pertama yaitu bahan baku yang memiliki nilai sebesar 0,778 dan indikator yang kedua yaitu kualitas dan tampilan memiliki nilai sebesar 0,764 . Untuk nilai dari variabel promosi yang tercermin dari indikator periklanan memiliki nilai sebesar 0,864. Dan untuk nilai dari variabel keputusan pembelian memiliki nilai sebesar 0,749. Dari hasil uji validitas dan reliabilitas tersebut didapatkan nilai cronbach alpha diatas 0,7 dari semua variabel, sehingga dapat dikatakan bahwa instrumen penelitian ini dapat diandalkan.

\section{Uji t dan Uji F}

Untuk membuktikan hipotesis yang telah digunakan, maka dapat diuji menggunakan uji regresi. Uji regresi dilakukan untuk mengetahui Pengaruh variabel independent terhadap variabel dependen.

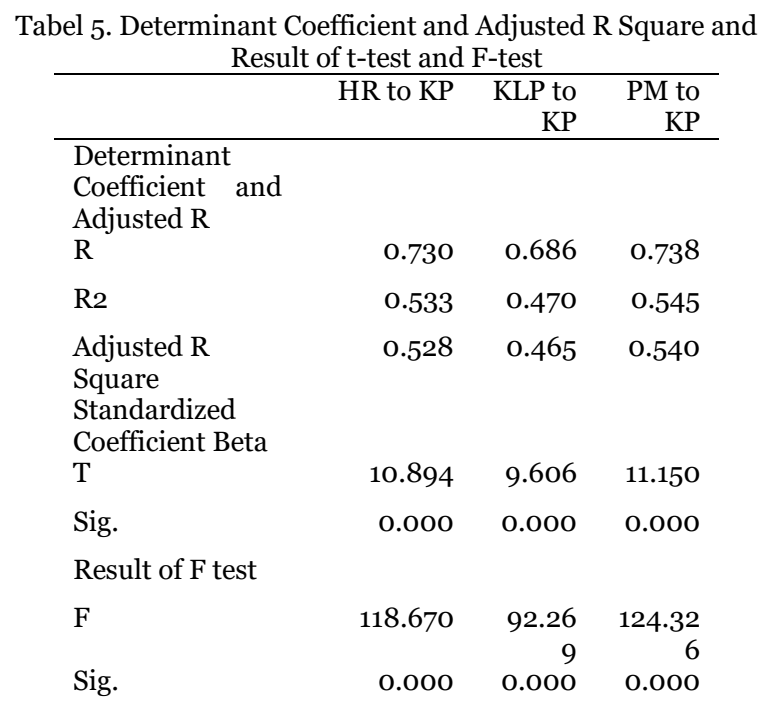

Sumber: Data diolah oleh Peneliti 2020

Dari hasil uji hipotesis yang pertama, didapatkan nilai $\mathrm{R}$ yaitu 0,730 , untuk nilai $R 2$ yaitu 0,533, dan untuk nilai adjusted $R$ Square yaitu 0,528 . Untuk nilai dari adjusted R square dapat dilihat bahwa $52 \%$ dari variabel keputusan pembelian dipengaruhi oleh harga, sedangkan 48\% dipengaruhi oleh variabel lainnya.

Harga berpengaruh positif dan signifikan terhadap keputusan pembelian. Dapat dilihat bahwa hasil uji regresi didapat nilai sebesar 0,533 dengan nilai hitung $\mathrm{T}$ sebesar 10.894 dan signifikan sebesar o,000 yang dimana signifikan ini lebih kecil dari 0,05. Nilai yang lebih kecil dari 0,05 ini berarti bahwa harga dari pattaya corner benar-benar mempengaruhi konsumen dalam proses pengambilan keputusan pembelian.

Didapatkan bahwa dalam nilai uji $\mathrm{F}$ yang pertama sebesar 118.670 dengan nilai signifikan sebesar 0,ooo. Hasil ini menunjukkan bahwa variabel harga berpengaruh signifikan terhadap keputusan pembelian. Oleh karena itu, H1 dalam penelitian ini diterima. 
Dari hasil uji hipotesis yang kedua, didapatkan bahwa nilai $\mathrm{R}$ yaitu 0,686 , untuk nilai R2 sebesar 0,470 , dan nilai addjusted R Square sendiri yaitu 0,465 . Dari nilai Adjusted $\mathrm{R}$ Square didapat bahwa $46 \%$ keputusan pembelian dipengaruhi oleh kualitas produk, sedangkan $54 \%$ dipengaruhi oleh faktor lainnya.

Kualitas produk berpengaruh positif dan siginifikan terhadap keputusan pembelian. Didapatkan bahwa nilai uji regresi sebesar 0,470 dengan nilai hitung $\mathrm{T}$ sebesar 9.606 dan signifikan yaitu o,ooo yang mana nilai ini lebih kecil dari o,05. Hal ini menyatakan bahwa, apabila kualitas produk meningkat maka pengambilan keputusan akan produk pattaya corner akan semakin meingkat. Pada hasil uji $\mathrm{F}$ yang kedua didapat nilai sebesar 92.629 dengan nilai signifikan yaitu 0,ooo. Hasil ini menunjukkan bahwa variabel kualitas produk berpengaruh signifikan terhadap keputusan pembelian. Oleh karena itu H2 dalam penelitian ini diterima.

Dari hasil tes yang ketiga, didapatkan bahwa nilai $\mathrm{R}$ yaitu 0,738 , untuk nilai $\mathrm{R} 2$ sebesar 0,545 , dan nilai untuk adjusted $\mathrm{R}$ Square sebesar 0,540. Dari nilai adjusted $\mathrm{R}$ Square dapat dilihat bahwa 54\% variabel keputusan pembelian dipengaruhi oleh promosi, sedangkan 46\% dipengaruhi oleh variabel lainnya.

Promosi berpengaruh positif dan signifikan terhadap keputusan pembelian. Dalam hasil uji regresi didapat nilai sebesar 0,545, dengan nilai uji t sebesar 11.150 dan signifikan sebesar 0,000 dan nilai ini lebih kecil dari 0,05. Nilai yang lebih kecil dari o,05 ini berarti bahwa, apabila promosi ditingkatkan, maka tingkat pengambilan keputusan pembelian produk pattaya corner oleh konsumen juga akan meningkat. Sedangkan dalam uji $\mathrm{F}$ didapatkan nilai sebesar 124.326 dengan nilai signifikan yaitu 0,000. Hasil ini menunjukkan bahwa variabel promosi berpengaruh signifikan terhadap keputusan pembelian. Oleh karena itu $\mathrm{H}_{3}$ dalam penelitian ini dapat diterima.

\section{KESIMPULAN}

Berdasarkan penelitian yang telah dilakukan, maka dapat diambil kesimpulan sebagai berikut:

a. Variabel harga, kualitas produk, dan promosi memiliki pengaruh positif dan signifikan terhadap keputusan pembelian. Hal ini menunjukkan bahwa keputusan pembelian Pattaya Corner Salatiga tergantung dari harga, kualitas produk, dan promosi yang diberikan.

b. Variabel kualitas produk secara dominan tidak mempengaruhi keputusan pembelian pattaya corner, karena hanya berpengaruh sebesar 46\% terhadap keputusan pembelian. Hal ini menunjukkan bahwa, keputusan pembelian produk dapat didapatkan dengan variabel lainnya.

c. Variabel promosi merupakan variabel yang memiliki pengaruh yang paling dominan terhadap keputusan pembelian pattaya corner karena memiliki nilai sebanyak 54\%.

\section{Saran}

Diharapkan untuk peneliti selanjutnya dapat menambahkan variabel-variabel baru dan memodifikasi model penelitian sehingga menghasilkan kebaharuan dan pembaruan untuk penelitian selanjutnya. 


\section{Daftar Pustaka}

Achidah, Nur, M. Mukery Warso, dkk. 2016. Pengaruh Promosi, Harga, dan Desain Terhadap keputusan Pembelian Sepeda Motor Mio GT (Studi Empiris Pada Produk Yamaha Mio GT di Weleri-Kendal), Journal Of Management, Vol. 2, No. 2

Agustin, Melita Yesi. 2016. Analisis Kualitas Produk Harga dan promosi Terhadap Keputusan Pembelian Motor Honda Vario (Studi Kasus Pada Tridjaya Motor Dealer Resmi Motor Honda Cabang Girian-Bitung), Jurnal Berkala Ilmiah Efisiensi, Vol. 16, No. 03: 472-483

Albab Al Umar, A., Mustofa, M., Fitria, D., Jannah, A., \& Arinta, Y. (2021). Pengaruh Label Halal dan Tanggal Kadaluarsa terhadap Keputusan pembelian Produk Sidomuncul. Jesya (Jurnal Ekonomi Dan Ekonomi Syariah), 4(1), 641-647.

Dinawan, Muhammad Rhendria. 2010. Analisis Faktor-Faktor yang Mempengaruhi Keputusan Pembelian(Studi Kasus Pada Konsumen Yamaha Mio PT Harpindo Jaya Semarang), Jurnal Sains Pemasaran Indonesia, Vol. 9, No. $3: 335-369$

Gerung, Christy Jacklin, Jantje Sepang, Sjendry L Loindong. 2017. Pengaruh Kualitas Produk, Harga, dan Promosi Terhadap Kpeutusan Pembelian Mobil Nissan X-Trail Pada PT Wahana Wirawan Manado, Jurnal EMBA, Vol. 5, No. $2: 2221-2229$

Jumiati dan Emilia. 2017. Pengaruh Harga Terhadap Keputusan Konsumen Membeli Rumah Tipe 36 Pada CV Perdana Laju Mandiri di Guntung Manggis Kota
Banjarbaru, Jurnal Scientific, Vol. 1, No. $1: 1-20$

Kuncoro, Mudrajat. 2013. Metode Riset Untuk Bisnis \& Ekonomi Bagaimana Meneliti dan Menulis Tesis?. Jakarta : Penerbit Erlangga

Kotler, Philip. 2002. Marketing Management. Jakarta Prenhallindo

Kristian, Denny, Rita Widayanti. 2016. Pengaruh Kulitas Produk, dan Harga Terhadap Keputusan Pembelian Sepeda Motor Honda Pada Mahasiswa Kampus 1UniversitaKrida Wacana, Jurnal Ilmiah Manajemen Bisnis, Vol. 16, No. $1: 45-58$

Malau, Harman. 2016. Manajemen Pemasaran Teori dan Aplikasi Pemasaran Era Tradisional Sampai Era Modernisasi Global. Bandung : Penerbit Alfabeta

Maslikhah. 2013. Melejitkan Kemahiran Menulis Karya Ilmiah Bagi Mahasiswa. Yogyakarta : TrustMedia

Prasetyo, Budi, Yunita Rismawati. 2018. Pengaruh Promosi Penjualan Terhadap Keputusan Pembelian pada PT Harhagunatama Lestari (Toserba Roma) Cabang Dakota, Jurnal Ilmiah Manajemen Ekonomi dan Akuntansi, Vol. 2, No. $2: 57-65$

Soehardi, S., Gobel, D., Soejatmiko, B., \& Syofiansur, M. (2020). Pengaruh Bunaken Brand, Promosi Dan Kualitas Pelayanan Terhadap Kepuasan Turis Domestik Dan Asing Di Provinsi Sulawesi Utara. Jurnal Ilmiah Manajemen Ubhara, 2(1), 9-19. https://doi.org/http://dx.doi.org/1 0.31599/jmu.v2i1.732

Sunyoto, Danang. 2016. Dasar-Dasar Manajemen Pemasaran (Konsep, 
Strategi, dan Kasus). Yogyakarta : CAPS

Sunyoto, Danang. 2016. Strategi Pemasaran. Yogyakarta : CAPS

Widastuti, Hesti, Sri Yuni Widowati. 2014. Analisis Faktor-Faktor yang Mempengaruhi Keputusan Pembelian (Studi Kasus pada Mie Jakarta 69 Jl. MT. Haryono No.
914B, Semarang), Fokus Ekonomi, Vol. 9, No. $1: 1-10$

Zulaicha, Santri, Rusda Irawati. 2016. Pengaruh Produk dan Harga Terhadap Keputusan Pembelian Konsumen di Morning Bakery Batam, Inovbis : Jurnal Inovasi dan Bisnis, Vol. 4, No. 2 : 121-136 